\title{
ガラス／エポキシ積層板の破壊じん性に及ぼす 板厚・試験片寸法の影響についで
}

$\begin{array}{lllll}\text { 川田宏 } 之^{*} & \text { 大塚敏 弘* } \\ \text { 梶谷 } & \text { 正** } & \text { 林 郁 彦*** }\end{array}$

\author{
Effects of Thickness and Specimen Size on Fracture Toughness \\ of Glass/Epoxy Laminates \\ by
}

\author{
Hiroyuki KaWADA*, Toshihiro OtsukA*, Tadashi KaJitani** \\ and Ikuhiko HAYASHI***
}

Three points bending tests were conducted on specimens of plain woven glass cloth/epoxy laminates (fiber volume fraction $\fallingdotseq 0.4$ ) with notch and $R$ curves were obtained. The effects of the thickness and the size of the specimens on the fracture toughness were investigated. The crack propagation was experimentally observed with the ink method. The electric potential method and the acoustic emission method were carried out to detect the initiation of the crack. In this study, the validity of these nondestructive inspection method was examined corresponding to the loaddisplacement curves.

The following results were obtained: (1) the effect of the thickness on the fracture toughness was less than that of the specimen size, (2) the outputs in the electric potential method were correlatable with the initiation of the damage and the propagation of macroscopic crack, and classified into three distinct patterns and (3) $\mathrm{AE}$ counts gave so much information for the fracture behavior in such a way that the initiation of the damage and the proportional limit corresponded to the initiation and the rapid increase of the $\mathrm{AE}$ event counts, respectively.

キー・ワード：複合材料, 破壊じん性, き裂進展抵抗曲線, 電位差法, $\mathrm{AE}$ 法

\section{1 緒言}

切欠きを有するガラス／エポキシ複合材料の破壊は 切欠き近傍の損傷が複雑であり，不安定破壊に至るま で相当量の安定き裂成長があることが知られている. 近年, 破壊力学の体系化にともない複合材料に対する 適用が試久られ，安定き裂の発生点飞着目した研究や， 不安定き裂が伝ぱするときの破壊じん性值を対象とし た研究がなざれている. B.D. Agarwal らはコンプラ イアンスの変化からき裂の進展量を算出し, 鈴木らは 着色法によりき裂進展量を求め, それぞれき裂進展抵 抗曲線（ $R$ 曲線）を得ている.

一方， $R$ 曲線を求めるのには多数本の試験片を必要 とするのに対し, 電位差法, $\mathrm{AE}$ 法は一本の試験片に より破壊開始点を決定できる非破壊検査法であり，金 属材料を中心にその適用が議論されている. 複合材料 では導電材である CFRP に扔いて電位差法の適用例
があるが，不導電材である GFRP にはその例がない。 $\mathrm{AE}$ 法においては，その原理から複合材料に用いられ る場合が多く，破壊開始点を得ることがなされている が，界面はく離と強化材の破壊が混在する複合材料の き裂発生に関する研究への適用について, その可能性 が検討され始めたばかりである.

損傷の発生後む相当量の載荷能力がある複合材料に おいて，損傷の発生点に和けるじん性值と複合材料の 強化部材である繊維の破壊開始点に和けるじん性值は それぞれ最大荷重点に和けるじん性值に対する安全率 を示唆するるのと考光られ，材料の信頼性を明らかに する意味で重要である。李た，朰の検出方法はまちま ちでそれぞれの值はどのような意味をもつのか不明な 点が多い, 本研究では, 裂の進展量を着色法により 求め, 積層枚数, 試験片寸法が破壊じん性に及ぼす影 響について検討し，き裂の発生および破壞開始点をと

原稿受理 昭和59年 6 月11日 Received June 11, 1984

* 学生会員 早稲田大学大学院 東京都新宿区大久保, Graduate School, Waseda University, Okubo, Shinjuku-ku, Tokyo

** 早稲田大学理工学部 (現在, (株) 日立製作所), Faculty of Science and Engineering, Waseda University, Okubo, Shinjuku-ku, Tokyo

*** 正会員 早稲田大学理工学部 東京都新宿区大久保, Faculty of Science and Engineering, Waseda University, Okubo, Shinjukuku, Tokyo 
らえるのに電位差法, $\mathrm{AE}$ 法で調查する. 各手法につ いてそれぞれ荷重一荷重点変位曲線と対応させ，その 有効性を吟味する。

\section{2 実 験 方 法}

\section{$2 \cdot 1$ 供試材および試験片}

供試材は母材にエポキシ樹脂, 強化材として目抜き 平織ガラスクロスである. 板厚が破壊じん性に及ぼす 影響を調べる目的で 2 種類の板厚を設定し，繊維体積 含有率をほほ注一定 $\left(V_{f} \fallingdotseq 0.4\right)$ にした. その機械的性 質を Table I に示す。 また，スパン長さの影響を調 ベるために 2 種類の 3 点曲げ試験片 (3PB 試験片と略 記）を用いた. Fig. 1 に試験片形状と Table II に寸 法の組合せを示す．積層板から切り出す際に強化材の たて糸方向が試験片長手方向になるようにした．試験 片はすべて $\mathrm{EW}$ 試験片とし，予き裂は刃幅 $0.38 \mathrm{~mm}$ のダイヤモンドカッタを使用し，切欠き深さは $a / W$ $=0.5$ 一定とした.

Table I. Mechanical properties of specimens.

\begin{tabular}{c|c|c|c}
\hline $\begin{array}{c}\text { Young's } \\
\text { modulus } \\
E(\mathrm{GPa})\end{array}$ & $\begin{array}{c}\text { Knee point } \\
\text { stress } \\
\sigma_{\mathrm{knee}}(\mathrm{MPa})\end{array}$ & $\begin{array}{c}\text { Tensile } \\
\text { strength } \\
\sigma_{B}(\mathrm{MPa})\end{array}$ & $\begin{array}{c}\text { Elongation } \\
\phi(\%)\end{array}$ \\
\hline 20.0 & 68.4 & 247 & 1.47 \\
\hline
\end{tabular}

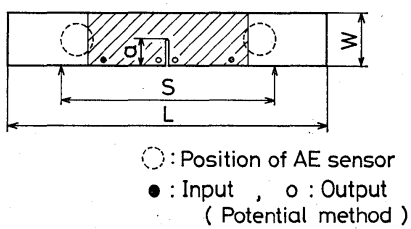

Fig. 1. Dimension of specimen.

Table II. Variation of specimen size (three points bending).

\begin{tabular}{c|c|r|r|r}
\hline $3 \mathrm{~PB}$ & $S$ & $L$ & $B$ & $W$ \\
\hline $3 \mathrm{~PB}(30 \mathrm{ply}, S=40)$ & 40 & 60 & 6 & 10 \\
$3 \mathrm{~PB}(50 \mathrm{ply}, S=40)$ & 40 & 60 & 10 & 10 \\
$3 \mathrm{~PB}(50 \mathrm{ply}, S=80)$ & 80 & 120 & 10 & 20 \\
\hline
\end{tabular}

\section{$2 \cdot 2$ 実験方法}

試験機は島津 オートグラフ IS-5000 を使用し，負 荷速度 $0.5 \mathrm{~mm} / \mathrm{min}$ 一定の条件で荷重一荷重点変位曲 線を求めた. 3 点曲げ試験の圧子点の直径は $10 \mathrm{~mm}$ とし，スパン長さは $40 \mathrm{~mm}, 80 \mathrm{~mm}$ の 2 種類である. 実験は恒温室にて行い, 雾曲気は温度 $20 \pm 2{ }^{\circ} \mathrm{C}$, 湿度 $50 \pm 5 \%$ 一定とした。樹脂の透明度を利用して透過光 による写真撮影を実験の各段階で行って, 損傷領域を 観察した。 $J$ 值の計算は次式を用いた.

\section{$J=2 A / B b \quad$ (Rice の簡便式)}

ここで，Aは荷重-荷重点変位曲線が囲も面積， $B$
は試験片厚さ， bはリガメント長さである・R曲線は 鈴木らの手法を参考にして行った. あらかじめ試験片 を多数本（10本以上）用意しておき，所定の荷重まで 負荷し荷重を20\%除荷する，インクを予き裂底より注 入乙約 1 分間浸透させる. 荷重を下げ充分乾燥した後, 着色された部分のスケッチを行う．画像処理装置によ り面積を求め, 板厚で除すことにより平均き裂長さ $\Delta a$ を算出した。 それぞれの荷重一荷重点変位曲線と $\Delta a$ よりR曲線を得た。

\section{$2 \cdot 3$ 非破壞検査法によるき裂の計測法}

着色法によりき裂長さを求める方法は正確な $R$ 曲線 を求められるが，多数本の試験片が必要である。した がって，1本の試験片でそのじん性值が得られる簡便 法の開発は重要な課題であろら。

電位差法を不導電材に適用するにあたって，試験片 表面に金を蒸着（厚さ $1.0 \sim 1.5 \times 10^{3} \AA$ ) 乙，試験片 表面におけるき裂の計測法を考案した。電流, 電圧端 子の取付け位置を Fig. 1 に示し，計測システムのブ ロック図を Fig. 2 に示す. 付加する電流は約 $10 \mathrm{~mA}$ 一定であり, 直流増幅器により出力を増幅し $\mathrm{X}-\mathrm{Y} レ$ コーダにて記録した，本研究において，蒸着された金 の厚さが比較的薄いために抵抗值は約 $2 \Omega$ と大きく, 安定した出力が得られた，電流を流すことによる発熱 の影響，金の蒸着による強度への影響は無視しうる。

$\mathrm{AE}$ 法は Physical Acoustic Corporation 社のモデ ル 3400 を使用した. 計測システムを Fig. 3 に示す. センサは PZT 素子からなる低周波用の $150 \mathrm{kHz}$ 共

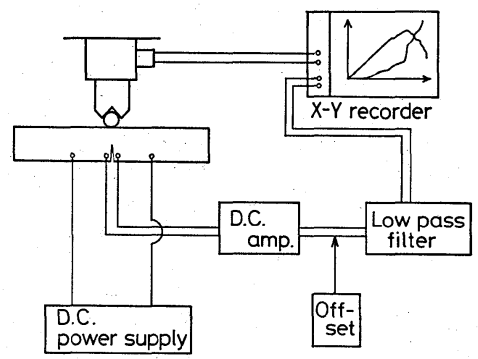

Fig. 2. Block diagram of electric potential difference method.

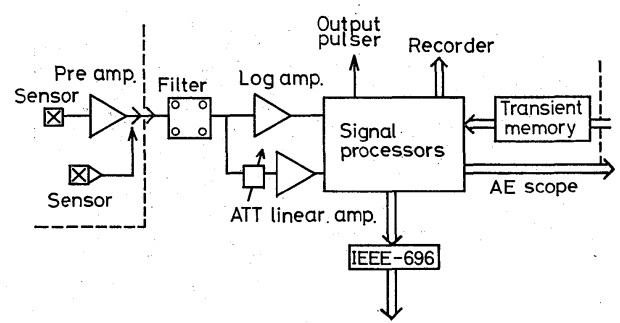

Fig. 3. Block diagram of acoustic emission method. 
振型のものを2 個使用した。センサを試験片に取付け るのに真空用グリース苍使用し，負荷治具と試験片々 の摩擦を防ぐをめにテフロンテープを使用した，本研 究では, 検知した $\mathrm{AE}$ 信号は前置增幅器, 带域万過器, 主増幅器により $40 \mathrm{~dB}$ の利得を得た。計測する $\mathrm{AE}$ パ ラメータはイベント，エネルギ計数を測定項目とした。

\section{3 実験結果および㭘討}

\section{$3 \cdot 1$ 破壞樣相}

Fig. 4 に 3 点曲げ試験 に牧ける 荷重一荷重点变位曲 線（以降，荷重一变位曲線と略す）拈よび透過光によ
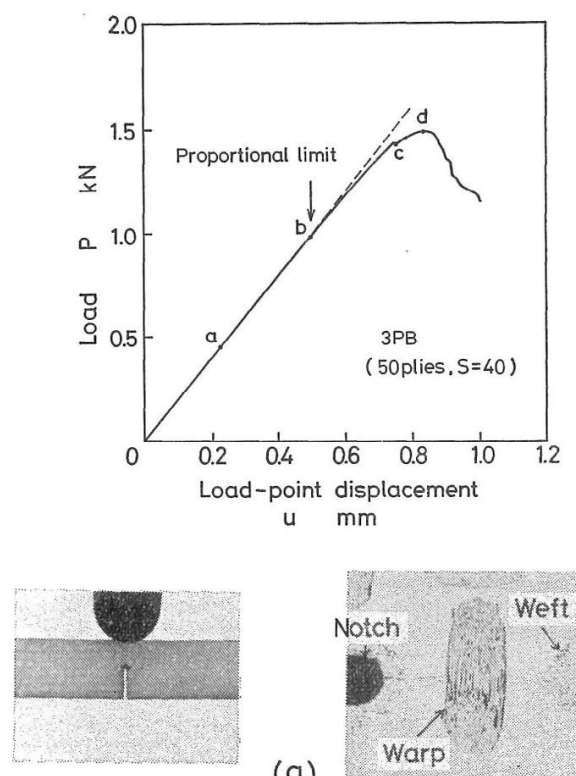

(a)
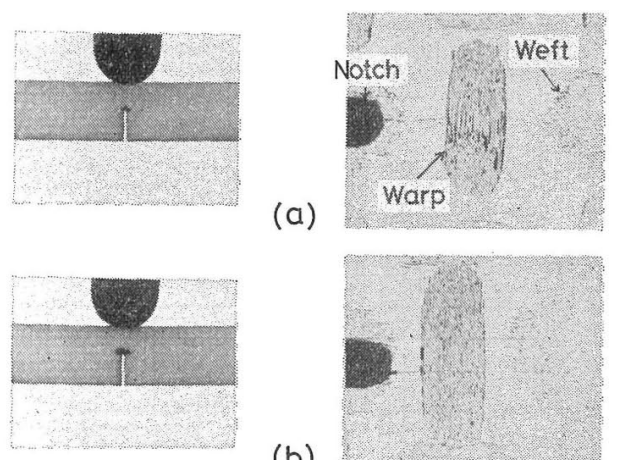

(b)
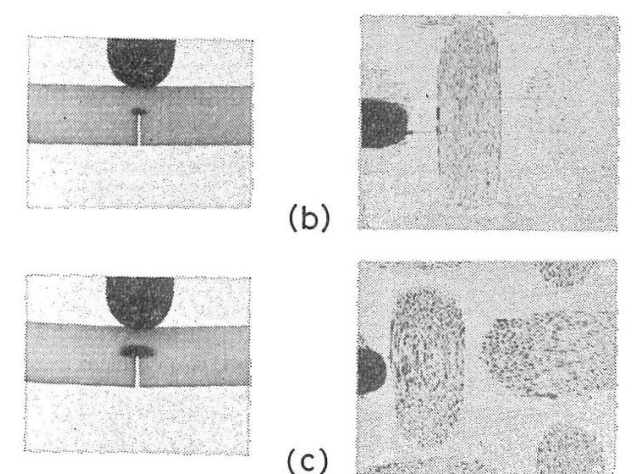

(c)
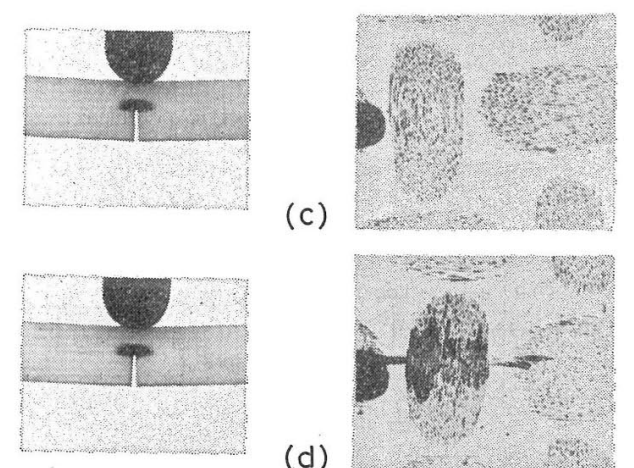

(d)

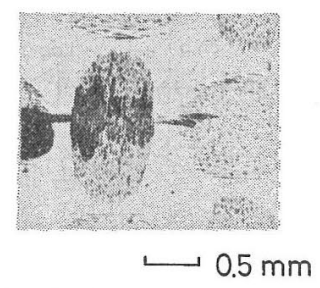

Fig. 4. Load-load point displacement curve and photographs showing damage at notch root.
る予き裂近傍の損賃領域の写真之との顕微鏡写真を示 す. 図中の各点は写真撮影を行った点と対応している. 図より最大荷重の約 $25 \%$ のとろで微視き裂が発生し ている.この微視き裂はたて繊維あるいはよこ瀻維に 沿ら母材との界面はく離である ( a 点). 荷重-変位曲 線は界面はく離の発生後も最大荷重の約 $67 \%$ まで線形 性を保つ。年の線形性を保つ b点は乞の比例限界であ る.顕微鏡写真よりたて䋐維の一部は破断しているが, 䋐維束単位の引抜きともなった破断怔生じていない c 点は最大荷重の直前に一時的飞荷重が低下する点で ある.たて瀻維束内を安定に伝ぱしていたさ裂が不安 定に繊維束内を進展するために生じた現象であり, 顕 微鏡写真では明りょらな繊維束の引抜きが観察される。 d 点は最大荷重点であり不安定き裂伝ぱの開始点であ る.

\section{$3 \cdot 2$ き裂進展抵抗曲線}

着色法によって平均き裂長さを求め, それを基盤と したR曲線を Fig. 5 に示す。本吴駼に入る前にき裂 のいるいるな着色方法学吟味した。除荷後, 破面を蕗 出さ䛧スケッチ起行ら際に比較的着色さ机た部分の輪

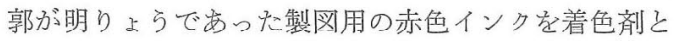
して使用した。図より板厚, 試験片寸法によらず，R 曲線は汪湢直線として近似できることが分る。本実験 の範团内で，スパン長が $R$ 曲線の折れ曲り点の存在に 及ぼす影響は認められなかった，R曲線の傾きた着目 すると 3 点曲げ試験片では, 添ぼ等しくなっているこ とが分る。

\section{$3 \cdot 3$ 積層枚数, 試験片寸法の影響}

積層枚数, 試験片寸法の破䘫じん性值に及ぼす影響 について険討するために, 荷重一変位曲線の比例限, 不安定き裂の発生点である最大荷重点に和けるこで性 值をとれぞれ $J_{p . l o}, J_{0}$ として Table III に示す. 本 研究では，主き裂の発生を支配するものとして強化部 材であるたて繊維の破断を考完た。すなおち，供試材 のような $0^{\circ} / 90^{\circ}$ ク口六積層材の場合, 試験片長手方 向に配列されたたて繊維が荷重の大部分を支克, 乞の 破断が破壤へ導くと考克るのが合理的であるう， J J . . . は界面はく離もしくは乎材の破壞から繊維破断へと進 んだ遷移点であると考党られよう。

Table III ょり，同じ試験片寸法 $(S=40 \mathrm{~mm})$ に ついて積層枚数によるじん性值への影響を比較すると,

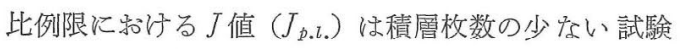
片の方がやや低い值を示しているが，最大荷重点に和 けるJ値 $\left(J_{c}\right)$ は添添等しい，比例限に和けるじ几性 值は最大荷重点のそれと比べてばらつきが大きいこと が表上り分る。これは荷重一変位曲線上に扔いて比例

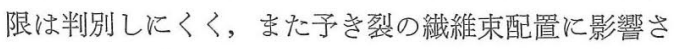
れたためにばらついたるのと思われる。本研究の複合 


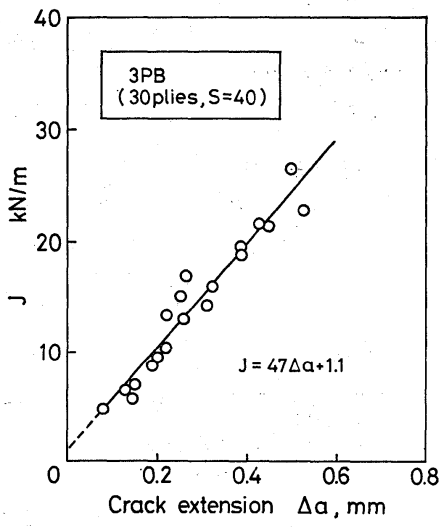

(a)

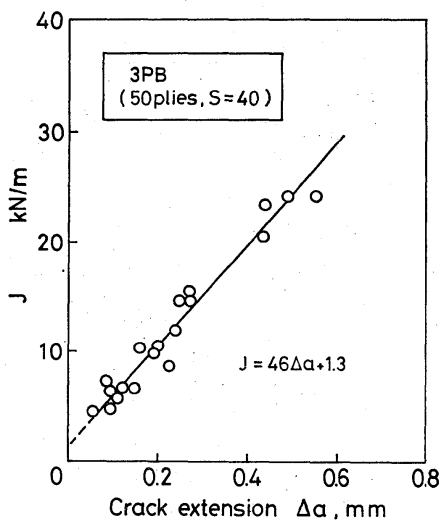

(b)

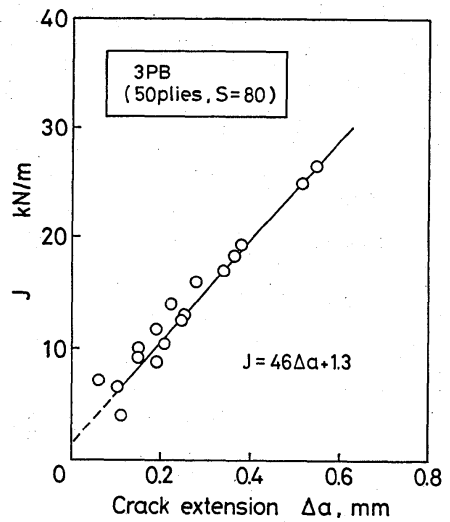

(c)

Fig. $5 . \quad R$ curves for three points bending specimens.

材料のように瀻維と母材との界面強度が著しく低い材 料飞和いて，比較的低い荷重で局所的な積層板の層間 はく離が生じるため，本研究の積層枚数の範囲内では， 積層枚数の影響は少ないと考兄られる.さらに，同じ 積層枚数を有する試験片に対して試験片寸法が破壊じ ん性值に及ぼす影響について調べると，試験片寸法の 小さな方が最大荷重点に括汀るJ值はやや高い值を示 していることが表より分る。これは, 試験片寸法の增
Table III. Fracture toughness values of three points bending specimens.

\begin{tabular}{|c|c|c|}
\hline Type of specimen & $J_{p . l .}(\mathrm{kN} / \mathrm{m})$ & $J_{c}(\mathrm{kN} / \mathrm{m})$ \\
\hline \multirow{7}{*}{$\begin{array}{c}3 \mathrm{~PB} \\
(S=40,30 \text { plies })\end{array}$} & 6.27 & 30.0 \\
\hline & 6.37 & 27.6 \\
\hline & 7.45 & 27.8 \\
\hline & 8.92 & 29.8 \\
\hline & 6.17 & 30.0 \\
\hline & 8.13 & 25.7 \\
\hline & 8.33 & 28.5 \\
\hline Average & 7.38 & 28.5 \\
\hline \multirow{7}{*}{$\begin{array}{c}3 \text { PB } \\
(S=40,50 \text { plies })\end{array}$} & 9.02 & 26.6 \\
\hline & 9.53 & 28.4 \\
\hline & 7.64 & 27.9 \\
\hline & 8.04 & 30.9 \\
\hline & 8.72 & 29.5 \\
\hline & 6.37 & 28.5 \\
\hline & 9.51 & 26.3 \\
\hline Average & 8.40 & 28.3 \\
\hline \multirow{7}{*}{$\begin{array}{c}3 \mathrm{~PB} \\
(S=80,50 \text { plies })\end{array}$} & 9.80 & 28.7 \\
\hline & 7.45 & 26.0 \\
\hline & 7.74 & 27.3 \\
\hline & 9.60 & 26.9 \\
\hline & 9.80 & 27.2 \\
\hline & 11.6 & 27.0 \\
\hline & 10.0 & 25.6 \\
\hline Average & 9.43 & 27.0 \\
\hline
\end{tabular}

大にともない損傷領域が，試験片寸法に比へてて小規模 になるためであると考党られる。，一方，比例限に和け るJ值は，積層効果を議論したときと同様にばらつき を示していることが分る。本研究では，表に示したよ うな実験結果になったが，比例限に乱汸るじん性值に 関する寸法効果の厳密な議論はできない，前述の $R$ 曲 線による結果では，これらの違いはき裂長さの平均值 を測定しているため，反映されなかったと考劣られる.

\section{$3 \cdot 4$ 非破壊検查法によるき裂の計測}

本研究では, 単一試験片による複合材料のき裂検出 法を吟味し，たて纎維の破断をともなら主き裂の発生， あるいは巨視き裂の発生を非破壊的に検出する合理的 な手法について検討する.

$3 \cdot 4 \cdot 1$ 電位差法による検討 電位差法を 3 点曲 げ試験に打いて適用した。負荷治具と蒸着面との接触 による短絡を防ぐために，Fig.1 の斜線の領域に限定 して金を蒸着した．Fig. 6 は Fig.1 に示した入出力 端子位置によるき裂長さと電位差の変化を較正曲線と して示したものである.次式は等角写像法による片側 き裂付平板に和ける解析解で㐫り，図中に実線でその 結果を示した.

$$
\begin{aligned}
& V(a) / V\left(a_{0}\right) \\
& \quad=\cosh ^{-1}\left(\frac{\cosh (\pi y / 2 W)}{\cos (\pi a / 2 W)}\right) / \cosh ^{-1}\left(\frac{\cosh (\pi y / 2 W)}{\cos \left(\pi a_{0} / 2 W\right)}\right)
\end{aligned}
$$

ここで, $V(a)$ はき裂長さ $a$ のきの電位差, $V\left(a_{0}\right)$ はき裂長さ $a_{0}$ のときの電位差，Wは板幅そして $y$ は 


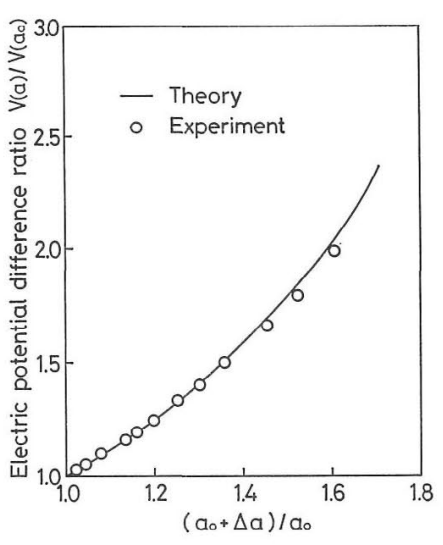

Fig. 6. Calibration curve for electric potential difference method.

き裂中央から電圧端子杂での距離で方る. Fig. 6 亿示 した較正曲線を得るために，き裂は予き裂からカッタ ーナイフにより表面をけがくことで進展させた。図よ り本研究で設定した入力端子の位置で泳ぼ理論值と実 験值が一致していることが分る，表面に物けるき裂の 計测を行らにあたり，内部と表面の裂進展の様相の 対応関係は重要である。そこで，き裂前緑の样子を先 の着色法により着色された領域として Fig. 7 飞示す. これよりきき裂前縁の形状は複雑で西り凸凹を示して いるが，板厚方向の最弱部で発生したき裂が連結すれ ば，板幅方向に一様に進展して和り，積層材に和ける 表面でのき裂計測は傾向として内部のき裂と対応して いる.

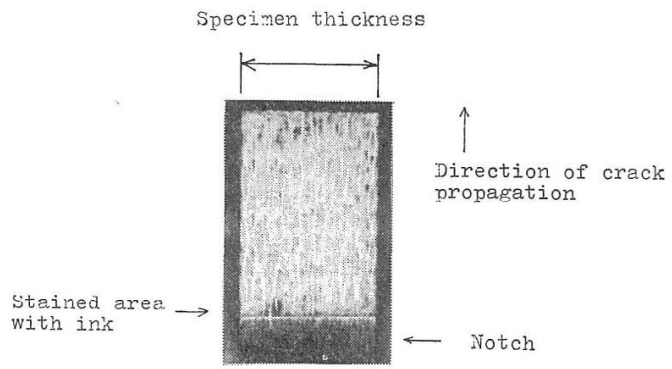

Fig. 7. Fracture surface.

Fig. 8 10 ヒス ゚゚ン長さ $80 \mathrm{~mm}$ ，積層枚数 50 層の 代表的な荷重一变位曲線, 電位差变化を示す。初期の 電位.差の変化に着目してみると, 肉眼で観察された損 倁の発生時期とほぼ対応して電位差の増加が生じてい ることが分る. 切欠き先端の樹脂部の変形に対応して 電位差が添とえど增加しない理由として，蒸着された 金の厚さが薄くな特かつ果材はぜい性材であるために， 变形による電位差の変化は，微視き裂の発生によるそ れに比べて無視できるほど小さいことによるためであ ると考光られる. Table IV に損傷の発生に対応する

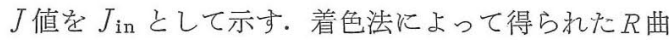

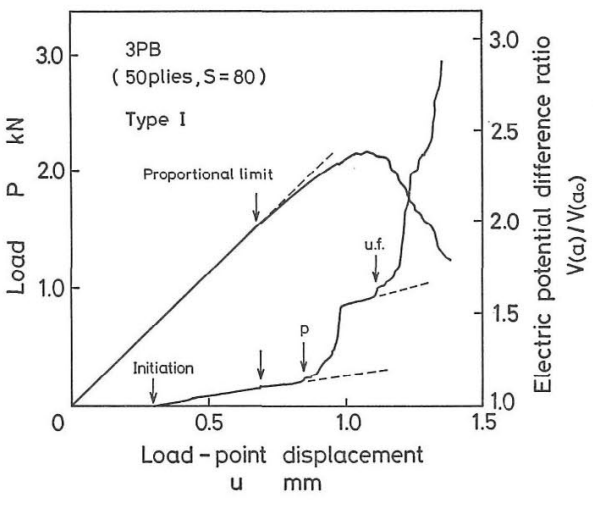

Fig. 8. Load and electric potential difference ratio vs. load point displacement.

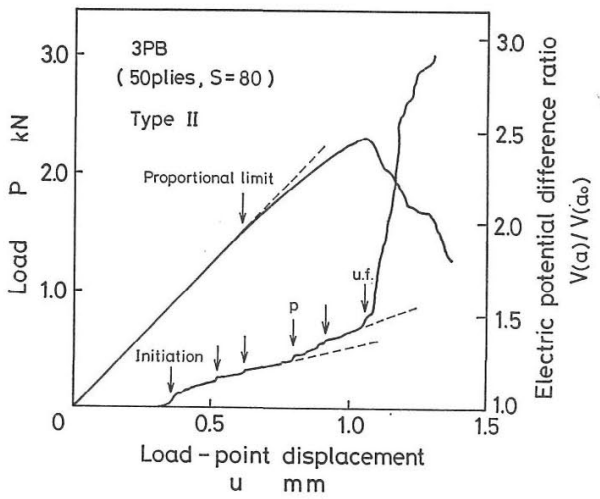

Fig. 9. Load and electric potential difference ratio vs. load point displacement.

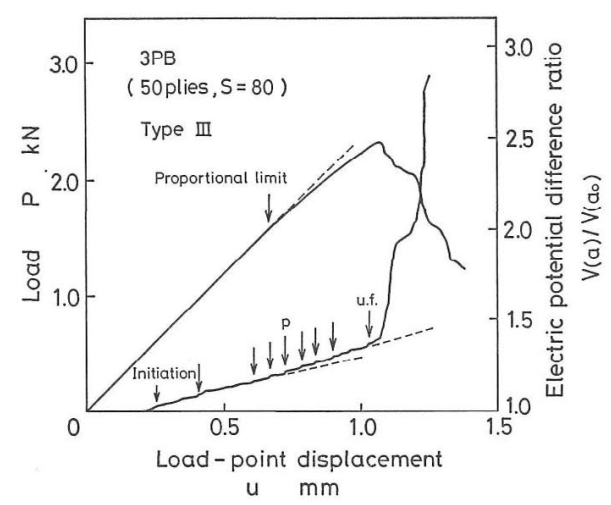

Fig. 10. Load and electric potential difference ratio vs. load point displacement.

Table IV. Comparison of $J$ values.

\begin{tabular}{c|c|c|c}
\hline Type of specimen & $\begin{array}{c}J_{\mathrm{in}(E P)} \\
\mathrm{kN} / \mathrm{m}\end{array}$ & $\begin{array}{c}J_{\mathrm{in}} \\
\mathrm{kN} / \mathrm{m}\end{array}$ & $\begin{array}{c}\mathrm{dJ} / \mathrm{da} \\
\mathrm{MN} / \mathrm{m}^{2}\end{array}$ \\
\hline $3 \mathrm{~PB}(30 \mathrm{ply}, S=40)$ & 1.5 & 1.1 & 47 \\
$3 \mathrm{~PB}(50 \mathrm{ply}, S=40)$ & 1.8 & 1.3 & 46 \\
$3 \mathrm{~PB}(50$ ply, $S=80)$ & 1.9 & 1.3 & 46 \\
\hline
\end{tabular}


線から $\Delta a \rightarrow 0$ として求められる $J_{\text {in }}$ と電位差法によ って測定される $J_{\text {in }}(E P)$ の值を比較すると，後者の 方が高めの值を示していることが分る．これは，R曲 線が平均き裂長さを採用していることと，損傷の発生 点として $\Delta a \rightarrow 0$ を仮定しているためであり，結果と して低めの值を示したものと考えられる.

損傷の発生点 (図中, initiation) から不安定き裂の 発生点 (図中, u.f.) までに安定き裂の発生点もしく はそれに伴らサブクラックの発生とみなせる電位差の ジャンプする点を各図に矢印で示した。同じ種類の試 験片形状に対して少なくとも15本の試験片に対して実 験を行ったが, 電位差の変化は試験片寸法, 積層枚数 が変っても本研究の範囲内ですべて 3 種類のタイプに 分類された.

電位差法によって得られた出力結果の分類を考える. (i)損傷の発生点に和汁る挙動である. 三つのタイプの 中で，タイプIIだけが顕著な立ち上がりを示して和り， 他の三つと区別される, (ii)比例限あたりの電位差のジ ヤンプする点の頻度の高いものとそらでないものの区 別である. その結果, タイプ吕とIが区別される. 図 に破線で示したように，比例限を過ぎたあたりに電位 差の巨視的な増加率が変化する点（図中，p）方存在 するが，その増加の割合の大きなものとそうでないも のの違いは, 先の電位差のジャンプ点の頻度と逆の対 応を示した. 以上の手順でもって，電位差法によって 得られた結果をすべて 3 種類のタイプに分類すること がでさた。予き裂近傍の試験片表面に和ける繊維束配 置と電位差の出力パターンとの対応関係を調べる，実 体顕微鏡にてあらかじめ予き裂が最初に位置する繊維 束配置の状況をスケッチして和き，実験を行った。そ の結果, 予き裂が位置する繊維束配置と電位差の出力 パターンは相関があることが分った。すなおち，タイ プ I は樹脂部，IIはよこ繊維束，IIIはたて繊維束にそ れぞれ予き裂の先端が位置していて，予き裂から発生 した界面はく離が，よこ繊維に沿う（タイプII）か, たて繊維に沿う（タイプIII）かで電位差の出力パター ンが特徴づけられる.タイプIは両者の混合型となっ ている.

さらに, 得られた対応関係之電位差の出力パターン の特徴を吟味する.タイプIIのように，よこ繊維に沿 ら界面はく離はモードIの開口型であり，その発生に 伴ら電位差の変化は, たて絨維に沿う界面はく離に比 ベてより顕著であると思われる。また，電位差のジャ ンプする点の頻度がタイプ吕において多くなる理由は， 予き裂から発生するサブクラックとたて繊維を破断す る回数がすべてのタイプの中で最も多いことによるた めであると考学られる。図より明らかなように，ず てのタイプで比例限前後で電位差のジャンプ点が集中
し，比例限を少し過ぎたあたりに電位差の増加率が変 化する実験結果は先の顕微鏡観察と良い対応を示して いる.

$3 \cdot 4 \cdot 2 \mathrm{AE}$ 法による検討 本研究で用いた電位 差法では, 試験片表面に拈けるき裂の発生を検出して いるため, 予き裂底の緎維束配置の影響を受けてしま い, 試験片内部の微視的破壊様相を直接にとらえられ ない.そこで，金属材料の破壊じん性試験に打いて， 非破壊検査法の一つとして成果を上げている $\mathrm{AE}$ 法を 用いて，荷重-変位曲線と微視的破壊様相との対応関 係を調ベる. 本研究で使用したAEセンサは直径が $\phi$ $17.4 \mathrm{~mm}$ のものである. 七ンサが取付け可能な試験 片はスパン長 $80 \mathrm{~mm}$ (50 層) のものであるために 1 種類の試験片を実験の対象とした. しきい值の設定は 白色雑音が感知されない值とした. 本研究では, $\mathrm{AE}$ 出力が突発型 $\mathrm{AE}$ 波形となることが予備実験において

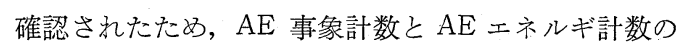
変化をとり上げた。

Fig. 11 に荷重一変位曲線とそれに対応する $\mathrm{AE}$ 事象 計数, $\mathrm{AE}$ エネルギ計数の変化を示す. 事象計数の変 化に着目すると先に見られた電位差の变化と良い対応 を示していることが分る. すなわち, 損傷の発生と同 時に事象計数が発生し, 荷重一变位曲線の比例限めた りに急増する傾向を示している. 電位差の変化が表面 に和けるき裂を計測したため予き裂底の繊維束配置の 影響を受けたのに対し, AE 法から得られた事象計数 の変化は, 試験片全体の微視的破壊を検知するために 試験片の違いによる明りょうな差異がなく, また, 電 位差法で得られたよらな三つの出力パターンは $\mathrm{AE}$ 法 では得られなかった. 一方, エネルギ計数の変化に着 目してみると，最大荷重の直前に一時的な荷重の低下 が生じる.いわゆる繊維束単位の引抜きを伴った巨視 き裂の進展時期から急激な立ら上がりを示しているこ とが分る。

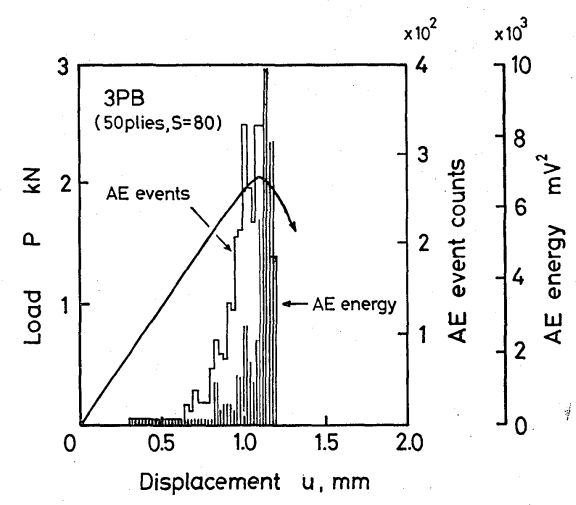

Fig. 11. Load-load point displacement curve and $\mathrm{AE}$ parameters. 


\section{4 結言}

予き裂を有するガラスノエポキシ積層板の破壊じん 性試験を行い，き裂の進展量を着色法に上り求め， $R$ 曲線を得た，破壊じん性に及济す積層枚数，試験片寸 法の影響について検討し，さらに，非破壞検査法であ る電位差法, $\mathrm{AE}$ 法にてき裂の発生, 進展の計測を行 い吟味し，以下の結論を得た。

（1）着色法により求めたさ裂長さから $R$ 曲線が得ら れ，損傷の発生点を $\Delta a \rightarrow 0$ のときの值として定義す ると, そのときの $J$ 值は積層枚数, 試験片寸法によら ず泳ぼ等しい， $R$ 曲線の傾きは，本研究の範囲内で添 ぼ同じとなったが，個々の破壊じん性試験の結果，本 研究の範囲内では積層枚数の影響は少なく, 試験片寸 法の影響をうけていることが分った。

（2）電位差法を積層板の破壞じん性試験に応用し， 試験片表面でのき裂計測を行った．表面においてき裂 を計測しているため，損傷の発生は $R$ 曲線のそれより 高めの值を示した．また，損傷の発生，巨視き裂の進 展に伴い電位差の変化が得られ，3種類のタイプに分 類され，予き裂底の纎維束配置との対応が得られた。

（3） AE 法により損傷の発生点，荷重-変位曲線 の 比例限注対応して事象計数の発生, 急増が生じ, 最大 荷重点の直前にェネルギ計数の急増点が観察された。

（4）電位差祆よび $\mathrm{AE}$ 法はそれぞれ試験片表面，内 部の微視的破壊様相を反映した出力結果を得た. それ らの結果は, 微視的観察との対応ができ, 破壊の様相 がより明らかとなった。

終りに, 本研究の遂行にあたり, 電位差法によるき 裂計測について有益なご教示をいただいた東京衡機 製造所(株)の藤井勉博士， $\mathrm{AE}$ 法で教世話になった伊
藤忠データシステム(株), 材料を提供して下さった旭 ファイバーグラス(株), 油化シェルエポキシ(株), 日 立化成(株)に心から謝意を表する.

(昭和59年 3 月 23 日 第13回 FRP シンポジウムにて講演)

\section{参 考 文 献}

1) 座古 勝, 森 孝男, 三好俊郎, 日本機械学会論文集, 45, 726 (1979).

2）鈴木 恵, 岩本正治, 村田泰清, 桐村和行, 日本機械学 会論文集，47，603 (1981).

3) 鈴木 恵, 岩本正治, 前岡 正, 日本機械学会論文集, 47, 10 (1981).

4) S. Gaggar and L. J. Broutman, Journal of Composite Material, 9, 216 (1975).

5）鈴木 恵, 岩本正治, 桐村和行, 田中信和, 日本機械学 会論文集，49，480 (1983).

6) B.D. Agarwal and G.S. Giare, Fibre Science and Technology, 15, 283 (1981).

7) 影山和郎，野中勝信，日本機械学会講演論文集，No. 840-2, p. 155 (1984).

8) H. Sekine, K. Shimomura, H. Takahashi and K. Fujino, First International Symposium on Acoustic Emission from Reinforced Composite, Session 3 (1983).

9）日本機械学会編, “弾塑性破壊勒性 $J_{\mathrm{Ic}}$ 試験方法”, p. 80 (1981) 日本機械学会.

10）白鳥正樹，三好俊郎，松下久雄，“数值破壊力学”, p. 239 (1980) 実教出版.

11) H. Tada, P. C. Paris and G.R. Irwin. "The Stress Analysis of Cracks Handbook" (1973) Del Research Corporation. 